\title{
Acquiring the English Language through Web-Based Role-Playing Simulations: Informal Learning in Interactive Environments
}

\author{
Yu-Chun Wang \\ Department of Applied Foreign Languages \\ National Kaohsiung University of Applied Sciences \\ 415 Chien Kung Road \\ Kaoshiung 807, Taiwan
}

Tel: 886-7-381-4526 \#3273 E-mail: willie_wang@kuas.edu.tw

Received: June 30, 2014 Accepted: July 8, 2014 Published: July 8, 2014

doi:10.5296/ijele.v2i2.5932 URL: http://dx.doi.org/10.5296/ijele.v2i2.5932

\begin{abstract}
The rapid evolution of technology has afforded students the opportunity to explore new pedagogies for learning English as a foreign language (EFL). This study focuses on exploring and understanding how foreign language teaching can be integrated with informal learning through the use of web-based role-playing simulations. The data gathered from two survey questionnaires were analyzed to serve the research purposes. The findings indicate that students enjoyed the immersive and interactive nature of a computer simulation that allowed them to interact with native speakers, and they thought that it improved their motivation to learn English. The results also suggest that engaging EFL students in authentic social interaction provides many benefits for developing their communicative competencies and promoting their interest in foreign language learning.
\end{abstract}

Keywords: foreign language acquisition, interactive web-based learning, communicative competence, informal learning, authentic communication 


\section{Introduction}

With the availability of computers and the Internet, learning environments are increasingly becoming more diverse and interesting. Over the past decade, online role-playing simulations have been used more and more frequently in a variety of educational contexts and disciplines including second and foreign language teaching (De Freitas, 2007). There are a number of pedagogical reasons for this growing utilization of online role-playing games. For example, in the case of language acquisition, simulation and gaming can compensate for the limitations of a traditional instructor-led course by allowing other language teaching methodologies to be introduced and experienced (Zheng et al., 2009). Similarly, the opportunity for EFL students to read, write and discuss issues within an authentic context helps them to acquire the language skills in an engaging and creative way.

The term informal learning first appeared in Knowles' book Informal Adult Education (1950). Since then, many authors have written about informal learning, offering their own views on the subject. Rogers (2004) suggested that informal language learning is unplanned and unpurposeful but it provides the most extensive learning as a result of daily life activities. Based on the theory of informal language learning, language can be acquired unconsciously and naturally outside of the traditional classroom setting through interaction with native speakers (Bahrani \& Tam, 2012). The typical formal learning environment is the classroom, whereas the many informal learning environments include the home, museum, and playgrounds. These days, the most popular informal learning spaces are virtual, such as blogs, social networks, simulations, chats and so forth. Virtual informal learning environments provide EFL students with authentic opportunities to acquire the language usage in a nonthreatening environment (Vialpando et al., 2005).

Scholars and practitioners both agree that communicative competence must be successfully demonstrated within true social contexts (Shih, Lin \& Yang, 2007). However, many EFL students lack access to native speakers for authentic communication (Chen, 2005). Due to its interactive nature of communication, computer-simulated environments appear to offer a good solution to the problem of a lack of language exposure beyond the classroom. Therefore, the aim of this study was to explore and understand how foreign language teaching can be integrated with informal learning through the creative use of web-based role-playing simulations.

\section{Literature Review}

\subsection{Informal Language Learning}

Cross (2006) defined informal learning as spontaneous, unstructured learning through which every individual acquires and gathers knowledge, skills, attitudes and insights from exposure to the environment outside of school through various mass media. Based on this definition, informal education is unorganized, unsystematic and even unintentional at times. According to Marsick and Watkins (1990), formal learning is typically classroom-based, highly structured and intentional. Other researchers (Merriam, Caffarella \& Baumgartner, 2007) have characterized formal and informal learning similarly. In formal learning situations, the 
students must set clear goals or objectives regarding what and how to learn. But in an informal learning scenario, the students usually select something that interests them. There are many platforms available for those seeking to learn informally. Social media and virtual platforms such as Facebook, Twitter and Second Life offer many opportunities for such informal learning.

The contrast between formal and informal instruction is also significant in debates around methods for the successful acquisition of a foreign language. Lightbown and Spada (2013) described informal language learning environments as the circumstances in which students are exposed to the target language, and formal language learning environments as the contexts in which the target language is being taught. In a formal language learning setting, the emphasis is placed on the language itself. In contrast, in an informal language learning setting, the emphasis is placed on meaning. In informal language learning contexts, students interact with native speakers from the target language country, use different technologies at home and work, watch movies, or listen to music as entertainment, all of which can lead to learning the language (Bahrani \& Tam, 2012). For example, EFL learners become indirectly involved in the language learning process when they try to understand an English movie or song.

\subsection{Web-Based Role-Playing Simulations and Foreign Language Acquisition}

As part of the general e-learning revolution, web-based education is rapidly becoming the primary instrument of education supported by classroom environments. Role-playing simulations, on the other hand, have long been used for recreational purposes. However, their use to enhance learning and teaching is a recent development. Empirical studies have shown that games and simulations can be effective tools for teaching complex subject matter (Garris, Ahlers, \& Driskell, 2002). Regarding EFL learning and instruction, online role-playing simulations provide students with opportunities to interact with native speakers. This allows them to develop their usage of English in a more natural context than a conventional classroom setting can offer (Zheng et al., 2009). Research has confirmed that students' satisfaction with learning in computer-simulated environments was high when engaged in authentic contexts (Reeder, 2010; Schwienhorst, 2002). In addition, cross-cultural communication becomes attainable in such environments (Barab et al., 2005). For these reasons, an increasing number of language educators are starting to view the online gaming environment as an active medium to supplement foreign language classes.

Several areas of interest have emerged for researchers who examine the effectiveness of computer-simulated environments for learning a language. These include the importance of the students' wishes, feelings, and attitudes in the learning process (Reeder, 2010). As discussed by Chen (2005), EFL students in countries where English is not the dominant language do not have the opportunity to acquire authentic, social, and cultural experiences within their educational circumstances. Simulations and gaming are able to bridge this gap between language instruction and its practical application. Roed (2003) suggested that virtual communities may provide a more relaxing and less stressful atmosphere than classrooms. Many simulations are designed with the potential to create low anxiety environments that 
foster positive and effective learning atmospheres, thus permitting the participants to try new behavioral patterns with a minimum of stress. This low level of inhibition and social anxiety could encourage some EFL students to increase their language production, particularly introverted students (Zheng et al., 2009).

Another element of simulations and gaming that optimizes the possibilities for language acquisition is the interaction. According to Vygotsky (1978), interactions promote learning. The exposure to authentic language input from computer-simulated environments not only provides students with opportunities to utilize what they learned during classroom instruction, but it also allows them to effectively communicate in a natural way. Kastoudi's (2011) findings suggest that it is worth creating virtual avatars for second language acquisition because these avatars can be beneficial mostly for interaction, negotiation and communicative competence.

\subsection{Second Life as an EFL Learning Platform}

Second Life (SL) is a web-based multi-user 3D virtual world developed by Linden Lab. Since its launch in 2003, SL has drawn the attention of researchers and practitioners, including foreign language educators by offering a variety of opportunities for interaction, a sense of community, and self-building capabilities for the users (e.g., Hislope, 2008; Wang et al., 2009). Some research studies have examined the effectiveness of teaching foreign languages in SL. To illustrate, Petrakou (2010) designed an English language course in higher education to allow students to practice their English with native speakers in the SL environment. The study found that the virtual world provided enhanced interactivity because it allows for synchronous communication and places the student in a spatial dimension. According to Petrakou (2010), the advantages of using SL for EFL students include gaining access to various online communities, interacting with different people from different countries and experiencing other cultures. SL might serve as a good place for students to converse with native speakers or other language students, especially those who are having difficulties in communicating with others in English. Warburton (2009) believes that SL is particularly appropriate for and relevant to teaching and learning foreign languages because it provides a simulated environment in which students can immerse themselves in appropriate linguistic learning contexts as well as interact and collaborate with others through text, voice, or video to achieve complex goals. However, it can also foster synchronous communication with native speakers in a fun and engaging way.

\section{Methodology}

\subsection{Research Questions}

To explore the benefit of using we-based role-playing simulations for foreign language acquisition, the following questions were addressed:

1. What is the potential value of online role-playing simulations for EFL learning?

2. How can foreign language teaching be integrated with informal learning through the use of online role-playing simulations? 
3. What are the students' perspectives on the use of web-based simulation technologies for foreign language acquisition?

\subsection{Contexts and Participants}

This study was conducted with the participation of 39 participants who were fourth-year undergraduate students from a technical university in southern Taiwan. The study aimed to collect the students' feelings and attitudes towards the use of web-based role-playing simulations in EFL writing lessons and to investigate the pedagogical value of simulation and gaming to support foreign language learning from an informal learning perspective. SL was chosen because it offers ample opportunities for active and interactive learning online. SL allows players to create and customize their own avatars, explore different environments and locations, socialize with other players, and participate in individual or group activities (Blasing, 2010; Jin, 2011). The participating students were engaged in several free online games within SL. Such a learning environment was contrasted with how English is taught in the traditional classroom in Taiwan. 28 native speakers from an American school in Taiwan were selected from a pool of 43 volunteers to interact with the participants online. The aim was to provide Taiwanese students with opportunities to reinforce their English by communicating synchronously with native speakers.

\subsection{Instruments}

The research data were collected from two online survey questionnaires. The first questionnaire was designed to survey students' initial impressions and experiences of SL, while mainly focusing on the questions of general feelings, ease of use and motivation to participate. The second questionnaire was designed to explore the students' language learning development by active interaction with native speakers on SL. To ensure the validity of both survey questionnaires, two experienced teachers, who had previously taught students at the same level were consulted, and they confirmed the validity of the questionnaires used in the study.

\subsection{Procedures}

As none of the participants had previous exposure to SL, several training sessions were held to familiarize students with the platform. The researcher was involved as a participant researcher. At the beginning of the study, the first online survey inquiring about students' initial impression on SL was administered to all participants. During the treatment period, a class schedule was instituted to bring the participants and the selected native speakers into several free adventure games within SL to communicate synchronously. In this virtual environment, the students could create and modify their own avatars to take new experience of different destinations within SL, such as Future City, Almost Wonderland, Elf Forest, and so forth. They could also interact with other users through communication tools (e.g., text and voice chats). Within SL, the students were required to only use English. By interacting with other players, the students shared thoughts and offered opinions from their own cultural experiences. The SL sessions were conducted twice a week in the computer lab and lasted 45 minutes. In addition to this, the students were encouraged to use SL on their home computers 
to experience new adventures and chat with native English speakers from all over the world. The treatment lasted 10 weeks. At the end of the research, the second online survey was conducted regarding the effects of the online role-playing simulations on the students' language improvement.

\section{Results}

The primary goal of the first online questionnaire was to survey the participants' initial impression of and experiences with the online role-playing simulations. The survey consisted of 10 statements and was a five-point Likert scale questionnaire. The survey asked the participants to express their views about using SL as a language learning tool, with the statement falling into three categories: (1) initial feelings, (2) ease of use, and (3) motivation and excitement. The results of the first survey are summarized in Table 1 and indicated the participants' initial learning experience was positive.

Table 1. Students' responses to the initial experiences using Second Life (SL) in an EFL course

\begin{tabular}{|c|c|c|c|}
\hline Statement & Mean & S.D. & Meaning \\
\hline \multicolumn{4}{|l|}{ Initial feelings } \\
\hline $\begin{array}{l}\text { 1. I felt comfortable using SL to interact with } \\
\text { others. }\end{array}$ & 4.02 & 0.86 & Positive \\
\hline $\begin{array}{l}\text { 2. I felt relaxed and free in the online gaming } \\
\text { environment. }\end{array}$ & 3.99 & 0.66 & Positive \\
\hline 3. I enjoyed exploring various destinations in SL. & 4.12 & 0.70 & Positive \\
\hline $\begin{array}{l}\text { 4. The online learning atmosphere was active and } \\
\text { real. }\end{array}$ & 3.87 & 0.71 & Positive \\
\hline
\end{tabular}

\section{Ease of use}

5. I found SL easy to use.

6. I found it easy to control the avatars.

7. I found it easy to navigate in SL.

\section{Motivation and excitement}

8. Participation in role-playing games improved my 4.02 motivation to learn English.

9. I enjoyed using SL either for my personal 3.97 pleasure or for my studies.

10. I was excited to chat online with native 4.21 speakers.

\begin{tabular}{llll}
\hline Average & 4.03 & 0.68 & Positive \\
\hline
\end{tabular}

The participants' language learning development and perceptions of SL as an EFL learning platform were revealed through the second online survey questionnaire. The survey consisted of 15 statements on a five-point Likert scale questionnaire. Of the 15 statements, 5 were about the participants' feelings towards interaction and role-playing through SL; 5 statements investigated the participants' language improvement after using SL as a language learning platform; and 5 statements addressed the participants' perceptions about learning English 
through SL, particularly with regard to the informal virtual learning environment and their experiences. The analysis of the second survey also yielded positive results (Mean Score = 4.07), as indicated in Table 2.

Table 2. Students' language learning development and perceptions of Second Life (SL) as an EFL learning platform

\begin{tabular}{|c|c|c|c|}
\hline Statement & Mean & S.D. & Meaning \\
\hline \multicolumn{4}{|l|}{ Interaction \& Role-Playing } \\
\hline $\begin{array}{l}\text { 1. I felt comfortable interacting with others through } \\
\text { online role-playing games. }\end{array}$ & 4.01 & 0.77 & Positive \\
\hline $\begin{array}{l}\text { 2. Online role-playing simulations offered } \\
\text { opportunities for social interaction among a group } \\
\text { of people. }\end{array}$ & 4.22 & 0.69 & Positive \\
\hline $\begin{array}{l}\text { 3. SL allowed me to interact with users from various } \\
\text { cultural backgrounds. }\end{array}$ & 4.05 & 0.65 & Positive \\
\hline $\begin{array}{l}\text { 4. The interaction with other players helped to } \\
\text { improve my social and interpersonal skills. }\end{array}$ & 3.98 & 0.83 & Positive \\
\hline $\begin{array}{l}\text { 5. Using avatars to interact online encouraged me to } \\
\text { learn from native speakers. }\end{array}$ & 4.12 & 0.72 & Positive \\
\hline
\end{tabular}

\section{Foreign Language Learning}

6. The opportunities for authentic communication helped me to become aware of my weaknesses in English.

7. Chatting online in English helped me to consolidate my vocabulary and learn new expressions.

8. By communicating synchronously, the native

$3.92 \quad 0.66 \quad$ Positive
speakers provided me with immediate feedback on my language usage.

9. The online learning mode enabled me to pay closer attention to my English writing skills.

10. I believed I could chat fluently in English online $4.00 \quad 0.58 \quad$ Positive after experiencing the SL platform.

\section{Perceptions \& Attitudes}

11. I found SL to be an effective language learning platform.

12. SL provided me with the opportunity to learn English in a more natural and less stressful environment.

13. Participation in the role playing adventures increased my desire to learn English.

14. Using SL as a language learning tool helped me to cultivate a positive attitude toward web-based

$4.13 \quad 0.81 \quad$ Positive

$4.21 \quad 0.63 \quad$ Positive

$4.00 \quad 0.58 \quad$ Positive

4.25

\subsection{Positive}

$3.99 \quad 0.59 \quad$ Positive

$\begin{array}{lll}4.17 & 0.67 & \text { Positive } \\ 4.04 & 0.80 & \text { Positive }\end{array}$


learning.

15. I enjoyed learning English in an informal language $3.97 \quad 0.69 \quad$ Positive learning environment.

\begin{tabular}{llll}
\hline Average & 4.07 & 0.70 & Positive \\
\hline
\end{tabular}

The results obtained from the second survey can be summarized as follows: the participants emphasized that engaging in the online role-playing games enabled them to interact with users from different cultural backgrounds and improve their communicative competencies. Playing these games also helped them to consolidate their vocabulary and at the same time to become more aware of their weaknesses in English. Most of the participants believed that the interaction with players who were native-speakers helped them to pay closer attention to their writing skills and provided them with immediate feedback on their language usage. Additionally, they confirmed that communicating synchronously with native speakers enabled them to learn new expressions and to be more confident when writing in English. Overall, they found SL to be an effective language learning tool that helped them to cultivate a positive attitude towards interactive web-based learning.

\section{Discussion}

From the perspective of the development and learning of a language, simulations and role-playing are particularly interesting. They reproduce a realistic situation that requires the understanding and use of the target language that is being acquired. Students engaging in the online gaming environment were required to use English to interact with one another. Through such practices, a greater awareness of English usage emerges. In this study, the students confirmed that interacting with native speakers in the SL environment improved their language usage skills. The interactive environment can support good language teaching because it provides a platform for informal communication, and this flexibility can provide advantages over a traditional lecture-based classroom.

Another benefit of using simulations in the EFL classroom is that students gained the ability to communicate well in English through social interaction. The students believed that their communicative competencies in English had improved after experiencing SL. The online communication with native speakers not only helped raise the students' awareness of their weaknesses in English, but it also enabled them to produce the English language in an authentic social context. Moreover, the authentic interactions in SL provide students with opportunities to learn about other cultures and acquire the ability to communicate across cultural frontiers.

In addition, the students expressed a high confidence in their use of English in computer simulation. For example, the students felt comfortable using avatars to chat online with native speakers. Their comfort and confidence play a critical role in improving fluency in a foreign language. The students also developed a positive attitude toward learning the English language. They perceived the use of online role-playing games as fun and simulating in comparison to learning English in the classroom. An interesting aspect that emerged was the reduction of some students' anxiety about learning a foreign language. The results indicated that virtual gaming environments can create a less stressful learning atmosphere than 
classrooms provide.

The positive opinion of this type of instruction in an EFL class confirmed the students' readiness to engage in such avatar-meditated informal learning activities. The data showed that the students enjoyed the interactive nature of SL and felt it increased their interest in learning English. Most of the students perceived SL as a very effective tool to improve learning a foreign language. However, some students did complain about problems related to Internet speed and compatibility issues with SL. These technical problems have the potential to discourage students from using SL as an online learning platform.

\section{Conclusion}

The findings in this study suggest that computer simulations and gaming can provide an appealing, user-friendly, and relevant space in which authentic language learning can be explored within an informal learning framework. In the computer-simulated environment, the students have opportunities to interact with native speakers in many different contexts and about many topics. This can fulfil the need to be exposed to varied input in the target language. The exposure to authentic language input intensifies communication and enhances opportunities for social and cultural interactions. This can be seen as a supplement to conventional language learning environments that opens up opportunities to convey language teaching in an exciting and interactive manner. Needless to say, EFL students can make use of web-based role-playing simulations for language improvement in an informal learning setting.

It is acknowledged that this study has several limitations. There is a need to further examine the dynamics of interaction between the EFL and native-speaking students and the impacts of these interactional patterns on the students' actual learning. Because this study was conducted with a small number of university students in southern Taiwan, the findings may not be generalizable to other populations. Future research is suggested that involves students with different backgrounds in different educational settings and over a much longer period. Nevertheless, the results have shed some light on the potential of web-based role-playing simulations for learning a foreign language.

\section{References}

Bahrani, T., \& Tam, S. S. (2012). Informal language learning setting: Technology or social interaction? Turkish Online Journal of Educational Technology, 11(2), 142-149. Retrieved from http://www.tojet.net/articles/v11i2/11215.pdf

Barab, S., et al. (2005). Making learning fun: Quest Atlantis, a game without guns. Educational Technology Research and Development, 53(1), 86-107. http://dx.doi.org/10.1007/BF02504859

Blasing, M. T. (2010). Second language in Second Life: Exploring interaction, identify and pedagogical practice in a virtual world. Slavic and East European Journal, 54(1), 96-117. Retrieved from http://www.personal.kent.edu/ cekline/sl1.pdf

Chen, Y. H. (2005). Computer mediated communication: The use of CMC to develop EFL 
learners' communicative competence. Asian EFL Journal, 7(1), 167-182.

Cross, J. (2006). Informal Learning: Rediscovery the Natural Pathways that Inspire Innovation and Performance. San Francisco, CA: Pfeiffer.

De Freitas, S. (2007). Learning in Immersive Worlds. A Review of Game-Based Learning. London: JISC.

Garris, R., Ahlers, R., \& Driskell, J. E. (2002). Games, motivation and learning: A research and practice model. Simulation \& Gaming, 33(4), 441-467. http://dx.doi.org/10.1177/1046878102238607

Hislope, K. (2008). Language learning in a virtual world. The International Journal of Learning, 15(11), 51-58.

Jin, S. A. (2011). Leveraging avatars in 3D virtual environments (Second Life) for interactive learning: the moderating role of the behavioral activation system vs. behavioral inhibition system and the mediating role of enjoyment. Interactive Learning Environments, 19(5), 467-486. http://dx.doi.org/ 10.1080/10494820903484692

Kastoudi, D. (2011). Using a quest in a 3D virtual environment for student interaction and vocabulary acquisition in foreign language learning. Proceedings of the EUROCALL 2011 Conference, (Vol.2, pp. 87-89).

Knowles, M. S. (1950). Informal adult education. New York: Association Press.

Lightbown, P. M. \& Spada, N. (2013). How Languages are Learned. (4 ${ }^{\text {th }}$ edition). Oxford: Oxford University Press.

Marsick, V. J., \& Watkins, K. (1990). Informal and Incidental Learning in the Workplace. London and New York: Routledge.

Merriam, S. B., Caffarella, R., \& Baumgartner, L. (2007). Learning in Adulthood: A Comprehensive Guide. ( $3^{\text {rd }}$ edition). New York: Wiley.

Petrakou, A. (2010). Interacting through avatars: Virtual worlds as a context for online $\begin{array}{llll}\text { education. Computers } \& \text { Education, } & \text { 54(4), }\end{array}$ http://dx.doi.org/10.1016/j.compedu.2009.10.007

Reeder, K. (2010). Edubba: Real-world writing tasks in a virtual world. In M. Thomas \& H. Reinders (Eds.), Task-based language learning and teaching with technology (pp.176-196). London \& New York: Continuum.

Roed, J. (2003). Language learner behavior in a virtual environment. Computer Assisted Language Learning, 16, 155-172. http://dx.doi.org/ 10.1076/call.16.2.155.15880

Rogers, A. (2004). Looking again at non-formal and informal education - towards a new paradigm, the encyclopaedia of informal education, Retrieved from www.infed.org/biblio/non_formal_paradigm.htm.

Schwienhorst, K. (2002). Why virtual, why environment? Implementing virtual reality 
concepts in computer-assisted language learning. Simulation \& Gaming, 33(2), 196-209. http://dx.doi.org/10.1177/1046878102332008

Shih, Y., Lin, Y., \& Yang, M. T. (2007). The development of an online virtual English classroom: VEC3D. Journal of Information Technology and Applications, Special Issue on Computer and Network Technologies in Education, 2(2), 61-68.

Vialpando, J., Yedlin, J., Linse, C., Harrington, M., \& Cannon, G. (2005). Educating English language learners: Implementing instructional practices. Providence, RI: The National Council of La Raza and the Education Alliance of Brown University.

Vygotsky, L. S. (1978). Mind in society. Cambridge, MA: Harvard University Press.

Wang, C. X., Song, H., Stone, D., \& Yan, Q. (2009). Integrating Second Life into an EFL program in China: Research collaboration across the continents, Tech Trends: Linking Research \& Practice to Improve Learning, 53(6) 14-19.

Warburton, S. (2009). Second Life in Higher Education: Assessing the potential for and the barriers to deploying virtual worlds in learning and teaching. British Journal of Educational Technology, 40(3), 414-426. http://dx.doi.org/10.1111/j.1467-8535.2009.00952.x

Zheng D., et al. (2009). Attitude and Self-Efficacy Change: English Language Learning in Virtual Worlds. CALICO Journal, 27(1), 205-231. Retrieved from

http://journals.sfu.ca/CALICO/index.php/calico/article/view/851/713

\section{Copyright Disclaimer}

Copyright for this article is retained by the author(s), with first publication rights granted to the journal.

This is an open-access article distributed under the terms and conditions of the Creative Commons Attribution license (http://creativecommons.org/licenses/by/3.0/). 